\title{
VALUE CHAIN SEBAGAI ALAT BANTU MENGANALISA LAPORAN LABA RUGI DALAM UPAYA PENCIPTAAN KEUNGGULAN BERSAING
}

\author{
Novi Nugrahani \\ Jurusan Akuntansi, Politeknik Negeri Malang \\ Jalan Soekarno Hatta No.9, Kota Malang, Jawa Timur 65141 \\ Email:nugrahani19@gmail.com
}

Abstract

The company's success relies on competitive advantages, namely submit products at low cost or provide unique benefits to the buyer are worth the premium price. One of the tools to support the achievement of competitive advantage that is of value chain. Value chain will separate the activities of the company's value, then analysis on the income statement so that the share of costs incurred in each of the activities and be further improvements or control on the activity. This research was conducted at the company $S$ and indicate where the main activity consists of marketing activities, planning, implementation and service. While support activities consist of purchasing activity and infrastructure. Activities that have a major influence is the implementation activities, because the company is engaged in the construction project.

Keywords: value chain, competitive advantage, company's value

Abstrak

Kesuksesan perusahaan bergantung pada keunggulan kompetitif, yaitu mengirim produk biaya rendah atau memberikan manfaat unik kepada pembeli dengan harga layak yang premium. Salah satu alat untuk mendukung pencapaian keuntungan kompetitif yaitu rantai nilai. Rantai nilai akan memisahkan kegiatan nilai perusahaan, maka analisis pada laporan pendapatan berbagi biaya dalam setiap kegiatan dan perbaikan lebih lanjut atau kontrol pada aktivitas. Penelitian 
ini dilakukan di perusahaan S dan menunjukkan kegiatan utama terdiri dari aktifitas, perencanaan, pelaksanaan dan layanan pemasaran. Sementara kegiatan dukungan terdiri dari pembelian aktivitas dan infrastruktur. Kegiatan yang memiliki pengaruh besar adalah implementasi kegiatan, karena perusahaan terlibat dalam proyek konstruksi.

Kata kunci: nilai jaringan, keuntungan kompetitif, nilai perusahaan

\section{PENDAHULUAN}

Lingkungan persaingan yang sangat kompetitif membuat perusahaan berfikir secara strategik. Tujuan strategik perusahaan adalah berusaha untuk mencapai dan mempertahankan suatu keunggulan bersaing agar dapat mempertahankan posisinya. Bentuk keunggulan bersaing dapat berukerpa harga yang lebih rendah dari harga yang ditawarkan pesaing untuk suatu manfaat yang sepadan (keunggulan biaya) ataupun pemberian manfaat yang unik yang lebih dari sekedar mengimbangi premi (diferensiasi).

Untuk mencapai keunggulan bersaing diperlukan suatu informasi biaya yang akurat, yaitu yang dapat mengetahui terjadinya biaya pada masing-masing aktivitas yang dilakukan perusahaan.Karena itu dibutuhkan alat analisis yaitu value chain (rantai nilai) yang pertama kali diperkenalkan oleh Michael Porter, yang tujuannya adalah setelah dilakukan identifikasi tahap-tahap value chain dimana perusahaan dapat meningkatkan value konsumen atau menurunkan biaya, maka keunggulan bersaing perusahaan dapat tercapai.

Laporan laba rugi perusahaan biasanya hanya menggambarkan kinerja perusahaan secara umum. Value chain akan membantu menganalisa laporan laba rugi sehingga memberikan informasi kepada perusahaan tentang kinerja masing-masing aktivitas nilai perusahaan, untuk selanjutnya dilakukan langkah-langkah pencapaian keunggulan bersaing perusahaan.

Kebutuhan akan jasa konstruksi masih dibutuhkan mengingat kebutuhan masyarakat berupa tempat tinggal. Karena itu perusahaan konstruksi harus meningkatkan daya saing dalam menghasilkan jasa yang berkualitas. Hal ini sesuai dengan Kerzner (2009:7) yang menyatakan agar sebuah perusahaan konstruksi sukses harus dapat memprediksi jadwal pekerjaan, mengestimasikan biaya dari proyek konstruksi tersebut sacara akurat, mengontrol kemajuan pekerjaan dan pengeluaran selama pelaksanaan konstruksi dan menyelesaikan proyek dengan selamat dan tepat waktu, harus sesuai dengan yang direncanakan dan spesifikasinya, memuaskan pelanggan dengan anggaran, mutu dan waktu yang diharapkan.

Berdasarkan latar belakang yang diuraikan sebelumnya maka permasalahan yang akan dibahas adalah aktivitas-aktivitas apa yang membentuk value chain 
perusahaan dan bagaimana value chain membantu menganalisa laporan laba rugi dalam upaya penciptaan keunggulan bersaing.

Penelitian mengenai value chain pernah dilakukan yaitu Analisis Value Chain sebagai Alat Strategic Cost Management Untuk Menciptakan Keunggulan Bersaing Dalam Upaya Meningkatkan Profitabilitas Perusahaan (Studi pada Unit Usaha Air Minum Dalam Kemasan (AMDK) ASA Perum Jasa Tirta 1 Malang) yang dilakukan oleh Kurrota Akyun (2013) yang menunjukkan bahwa aktivitas operation merupakan aktivitas dengan berbiaya paling besar dalam perusahaan. Penelitian lain dilakukan oleh Eka Denis Sumarsono (2014) dengan judul Analisis Rantai Nilai Sebagai Alat Untuk Mendukung Strategi Kepemimpinan Biaya (Studi Kasus Pada Perusahaan Kontraktor CV. Tunas Inti Surabaya), dengan hasil aktivitas pada CV. Tunas Inti terbagi menjadi dua aktivitas, yaitu aktivitas primer terdiri dari aktivitas pengadaan proyek, perencanaa, pelaksanaan dan pengawasan, penyerahan hasil proyek dan pemeliharaan hasil proyek dan aktivitas sekunder tediri dari aktivitas pengembangan sumber daya manusia dan infrastruktur perusahaan.Juga dilakukan oleh Annisa Lutfia (2012) dengan judul Analisa Pengaruh Value Chain Terhadap Persaingan Dalam Mencapai Kepuasan Pelanggan Pada Perusahaan Precast di Indonesia dengan hasil aktivitas value chain berpengaruh dalam peningkatan keunggulan bersaing dalam mencapai kepuasan pelanggan.

\section{KAJIAN PUSTAKA}

\section{Perkembangan Manajemen Biaya Strategik}

Manajemen biaya strategik adalah pengembangan informasi manajemen biaya untuk membantu fungsi manajemen utama yaitu manajemen strategik. Sehingga manajemen biaya strategik sangat penting untuk keberhasilan perusahaan atau organisasi.Menurut Shank dan Govindarajan (1993:8) tiga kunci utama manajemen biaya strategik ialah: analisis value chain, analisis strategic positioning, dan analisis cost driver.

\section{Konsep Analisis Value Chain}

Pengertian analisis value chain menurut Porter (1994:33) adalah suatu alat dasar untuk menguraikan perusahaan secara sistematik menjadi aktivitas-aktivitas yang relevan secara strategis untuk memahami perilaku biaya dan sumber diferensiasi yang sudah ada dan yang potensial. Tujuan dari value chain adalah untuk mengidentifikasi tahap-tahap value chain dimana perusahaan dapat meningkatkan value pelanggan atau menurunkan biaya. Sehingga dapat disimpulkan bahwa analisis value chain merupakan suatu alat analisis strategik yang menguraikan aktivitas perusahaan secara sistematik mulai dari pembelian bahan baku sampai dengan pelayanan ke konsumen. Analisis ini digunakan untuk memahami perilaku 
biaya dan sumber diferensiasi yang sudah ada yang potensial, sehingga nilai konsumen dapat ditingkatkan.

Analisis value chain membagi sebuah perusahaan membagi beberapa aktfivitas. Suatu rantai nilai (value chain) memperlihatkan nilai total, yang terdiri dari aktivitas nilai dan margin.Aktivitas nilai adalah aktivitas yang terpisah secara fisik dan teknologi yang diselenggarakan perusahaan ini merupakan balok-balok pembangun yang digunakan perusahaan untuk menciptakan produk yang berharga bagi konsumen.

Sedangkan margin merupakan perbedaan antara nilai total dan biaya kolektif pelaksanaan aktivitas nilai. Value chain pemasok dan penyalur juga mencakup margin yang penting untuk dipisahkan dalam memahami sumber posisi biaya perusahaan. Hal itu dikarenakan margin pemasok dan penyalur adalah bagian dari total biaya yang ditanggung pembeli.

Aktivitas nilai dapat dikelompokkan menjadi dua aktivitas besar, yaitu aktivitas primer (primary activities) dan aktivitas pendukung (secondary activities). Ada lima aktivitas primer meliputi semua aktivitas yang berhubungan dengan pengadaan bahan baku, proses produksi, penyimpanan barang jadi, pemasaran dan penjualan, serta pelayanan sesudah penjualan ke konsumen.

1. Inbound Logistics (Logistik ke dalam)

Merupakan aktivitas yang berhubungan dengan penerimaan, penyimpanan dan penyebaran masukan ke produk yang dapat berupa penangan bahan, pergudangan, pengendalian persediaan, pengaturan jadwal kendaraan, pengangkut dan pengembalian barang ke pemasok.

2. Operations (operasi)

Aktivitas yang berhubungan dengan pengubahan masukan menjadi produkakhir seperti permesinan, perakitan, pengemasan, penjahitan, pemeliharaan peralatan, pengoperasian fasilitas, pencetakan, dan pengujian.

3. Outbond Logistics (Logistik ke luar)

Adalah aktivitas yang berhubungan dengan pengumpulan, penyimpanan dan pendistribusian fisik produk ke pembeli seperti penggudangan barang jadi, penanganan bahan, operasi angkutan pengiriman, pemrosesan pesanan dan pengaturan jadwal pengiriman.

4. Marketing and sales (Pemasaran dan penjualan)

Merupakan aktivitas yang berhubungan dengan pemberian saran yang dapat digunakan pembeli agar dapat membeli produk dan berbagai upaya agar mereka mau untuk membelinya. Misalnya promosi, iklan, salesman, seleksi distributor, penetapan harta, penetapan target penjualan.

5. Service (pelayanan)

Aktivitas yang berhubungan dengan penyediaan pelayanan kepada pelanggan untuk meningkatkan atau mempertahankan nilai atau citra produk. Hal tersebut 
dapat berupa pemasangan, reparasi, garansi, pelatihan, pasokan suku cadang yang memadai dan penyesuaian produk.

Masing-masing aktivitas ini mungkin sangat vital untuk keunggulan bersaing bergantung pada industrinya. Dan dalam perusahaan apapun semua aktivitas primer akan ada pada kadar tertentu dan memainkan peran tertentu dalam keunggulan bersaing.

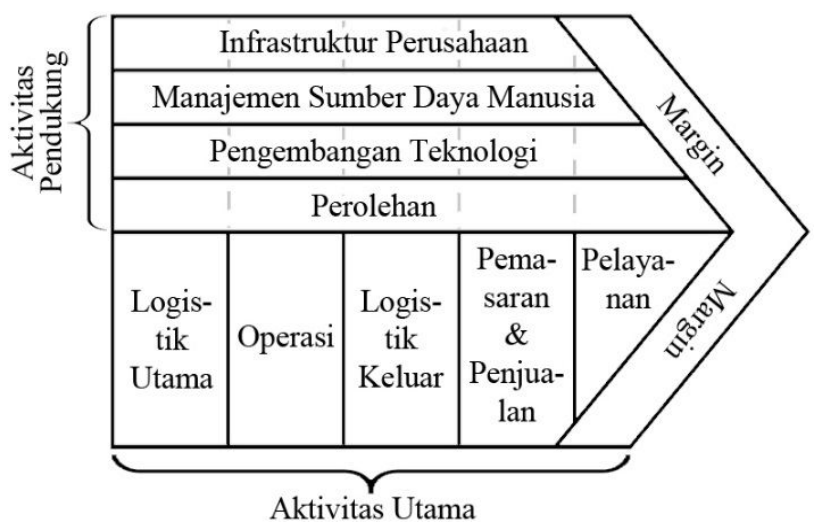

\section{Gambar 1. Konsep Analisis Value Chain}

Aktivitas pendukung adalah semua aktivitas yang mendukung aktivitas utama dan saling mendukung satu sama lain dengan memberikan masukan yang dibeli, pengembangan teknologi, penyediaan manajemen sumber daya manusia, dan penyediaan infrastruktur perusahaan. Berkaitan dengan aktivitas primer, aktivitas pendukung dapat dibagi menjadi beberapa aktivitas nilai yang berbeda yang khas untuk industri tertentu, yaitu

1. Procurement (Pembelian)

Aktivitas ini menyangkut fungsi pembelian masukan yang digunakan dalam rantai nilai perusahaan, bukan pada masukan yang dibeli itu sendiri. Masukan yang dibeli meliputi bahan baku, pemasok, bahan pendukung dan asset. Meskipun masukan yang dibeli biasanya dihubungkan dengan aktivitas primer, masukan yang dibeli ada di dalam setiap aktivitas nilai termasuk aktivitas pendukung.

2. Technologi Development (Pengembangan Teknologi)

Merupakan kumpulan aktivitas yang dapat dikelompokkan secara luas ke dalam usaha-usaha untuk memperbaiki mutu produk dan proses produksi. Setiap aktivitas nilai mengandung teknologi apakah berupa pengetahuan, prosedur atau teknologi yang terkandung dalam peralatan proses. 
3. Human Resources Management (Manajemen Sumber Daya Manusia) Kumpulan aktivitas yang meliputi perekrutan, pengangkatan, pelatihan, pengembangan dan kompensasi utnuk semua jenis tenaga kerja. Aktivitas ini akan menentukan keterampilan karyawan yang nantinya akan mempengaruhi keunggulan daya saing perusahaan.

4. Firm Infrastructure (Infrastruktur Perusahaan)

Sejumlah aktivitas yang meliputi manajemen umum, keuangan, akuntansi, hukum, perencanaan, manajemen mutu dan hubungan dengan pemerintah. Biasanya aktivitas ini akan menunjang aktivitas nilai keseluruhan dan bukan aktivitas tertentu saja. Infrastruktur perusahaan kadangkala dipandang sebagai biaya umum, namun dapat menjadi sumber yang kuat keunggulan bersaing.

Procurement, tecnologi development dan human resources dapat dihubungkan dengan aktivitas utama tertentu dan juga mendukung keseluruhan rantai. Sedangkan firm infrastructure tidak dihubungkan dengan aktivitas utama tertentu namun dapat mendukung apakah suatu perusahaan memiliki keunggulan bersaing.

Analisis laporan laba rugi perlu dilakukan untuk mengukur kinerja manajer, mengukur kelangsungan hidup perusahaan, melihat apakah perusahaan dalam melakukan telah mematuhi peraturan yang berlaku dan memberikan informasi untuk bagi investor untuk menanamkan modal bagi perusahaan.

Profit merupakan perbedaan antara pendapatan yang diterima dari hasil penjualan barang atau jasa dengan biaya yang digunakan untuk menghasilkan barang atau jasa tersebut. Perusahaan dikatakan mendapat profit apabila biaya yang dikeluarkan untuk menghasilkan produk atau jasa lebih kecil daripada harga jual.

Keunggulan bersaing pada dasarnya merupakan nilai yang perusahaan ciptakan untuk para pembelinya, yang dapat berupa keunggulan biaya, terjadi bila biaya kumulatif yang dikeluarkan perusahaan dalam melaksanakan aktivitas nilai lebih rendah dibandingkan dengan biaya kumulatif para pesaingnya, diferensiasi yaitu apabila perusahaan dapat memiliki keunikan dalam sesuatu yang dianggap penting oleh pembeli, selain lebih dari sekedar penawaran harga rendah.

\section{METODE PENELITIAN}

Penelitian ini merupakan penelitian deskriptif yaitu penelitian yang digunakan untuk menyelidiki keadaan, kondisi atau hal-hal lain yang sudah disebutkan, yang hasilnya dipaparkan dalam bentuk laporan penelitian Sugiyono (2013:3).Fokus penelitian ini hanya pada value chain dari aktivitas-aktivtas internal perusahaan saja, kemudian diarahkan untuk upaya pencapaian keunggulan bersaing perusahaan. Penelitian dilakukan pada perusahaan konstruksi "S" di Surabaya. Data yang digunakan terdiri dari dua jenis yaitu data primer dan data sekunder.Pengumpulan data dilakukan dengan cara survey pendahuluan, studi kepustakaan dan studi lapangan. Teknik analisis yang digunakan adalah sebagai berikut: 
a. Memilah-milah aktivitas yang dilakukan perusahaan untuk menentukan aktivitas mana yang membentuk value chain perusahaan

b. Melakukan analisis laporan laba rugi untuk masing-masing aktivitas value chain perusahaan

c. Membandingkan data perusahaan selama 2 tahun kemudian melakukan analisis untuk menentukan langkah-langkah perbaikan apa yang perlu dilakukan perusahaan dalam upaya penciptaan keunggulan bersaing.

\section{HASIL DAN PEMBAHASAN}

Perusahaan S merupakan sebuah usaha konstruksi yang berlokasi di Surabaya. Dalam menghadapi para pesaing, perusahaan selalu berusaha untuk tetap mempertahankan mutu dengan baik dengan harga kompetitif. Perusahaan merupakan pelaksana suatu proyek yang dipercayakan kepadanya oleh pemberi kerja (bouwheer).

Aktivitas yang dilakukan CV S adalah: (1) Penawaran (Project Marketing), merupakan aktivitas untuk mencari proyek bagi perusahaan.Hal tersebut dapat berupa dengan mengikuti tender ataupun melakukan penawaran terhadap pihak swasta atau perorangan. Untuk mengikuti tender dilakukan oleh Direktur sendiri yang dapat dibantu oleh bagian Teknik dan Operasional, sedangkan penawaran dengan cara lain dapat dilakukan oleh tiap-tiap fungsi dan akan mendapatkan sejumlah bonus; (2) Perencanaan (Planning Engineer) adalah aktivitas untuk melakukan perencanaan terhadap proyek yang akan dikerjakan perusahaan. Hal ini meliputi melakukan penghitungan teknik, hitung anggaran, survey harga dan pembuatan kontrak kerja. Aktivitas ini dilaksanakan oleh bagian Teknik dan Operasional; (3) Pelaksanaan (Produksi), merupakan aktivitas perusahaan untuk melaksanakan proyek yang meliputi pembelian bahan material, mobilisasi tenaga kerja, pelaksanaan proyek sendiri dan adanya pengawasan terhadapjalannya proyek dan kualitas pekerjaan.Pelaksana dari aktivitas ini adalah Manager Proyek dibantu Site Manager dan Site Engineer; (4) Keuangan dan Administrasi, aktivitas untuk melakukan penagihan biaya proyek kepada pemberi kerja dan pencatatan data akuntansi proyek.Aktivitas ini dilakukan oleh Manager Administrasi dan Keuangan yang membawahi Bagian Akuntansi, Kasir dan Administrasi. Sedangkan administrasi di lokasi proyek dilakukan oleh Administrasi proyek yang hasilnya nanti akan dilaporkan kepada Manager Administrasi dan Keuangan.

\section{Aktivitas Value Chain perusahaan}

Apabila dilihat dari fungsi unit yang terjadi dalam analisis aktivitas, aktivitas value chain dalam perusahaan konstruksi ini adalah merupakan setiap pertambahan nilai jasa yang diberikan oleh perusahaan untuk memenuhi kepuasan konsumen.

Aktivitas value chain perusahaan adalah sebagai berikut: (1) Pemasaran (Marketing and Sales), merupakan aktivitas untuk mencari proyek dengan 
mengikuti tender ataupun penawaran dengan cara lain, yaitu penawaran pada pihak swasta atau perorangan. Untuk mengikuti tender dilakukan oleh Direktur sendiri yang dapat dibantu oleh bagian Teknik dan Operasional. Sedangkan penawaran dengan cara lain dapat dilakukan oleh tiap-tiap fungsi dan akan mendapatkan sejumlah bonus. Selain itu perusahaan juga membuat brosur-brosur dan menjalin hubungan baik dengan para konsumen; (2) Perencanaan, adalah aktivitas untuk melakukan perencanaan terhadap proyek yang akan dikerjakan oleh perusahaan. Meliputi melakukan penghitungan teknik, hitung anggaran, survey harga dan pembuatan kontrak kerja.

Aktivitas ini dilaksanakan oleh bagian Teknik dan Operasional: (1) Pelaksanaan merupakan aktivitas untuk melaksanakan proyek yang meliputi pembelian bahan material, mobilisasi tenaga kerja, pelaksanaan proyek sendiri dan adanya pengawasan terhadap jalannya proyek dan kualitas pekerjaan.Pelaksana aktivitas ini adalah Manager Proyek dibantu Site Manager dan Site Engineer. (2) Service, merupakan aktivitas untuk memberi kepuasan kepada konsumen utnuk meningkatkan nilai jasa yang diberikan.Hal ini tercermin dengan adanya biaya pemeliharaan proyek dan biaya asuransi. (3) Pembelian (procurement), aktivitas untuk melakukan pembelian keperluan kantor, yang dilakukan secara merata oleh tiap bagian dalam perusahaan. (4) Infrastruktur (Firm Infrastructure), merupakan aktivitas yang mendukung kegiatan perusahaan secara keseluruhan.

\section{Analisis Laporan Laba Rugi dengan pendekatan value chain}

Laporan laba rugi perusahaan menyajikan pendapatan, biaya proyek, biaya operasi perusahaan dan laba perusahaan.Laporan ini kurang menunjukkan kinerja manajemen secara keseluruhan (faktor kualitatif) dalam rangka peningkatan keunggulan bersaing, profitabilitas, efisiensi, efektivitas dan produktivitas. Pendapatan merupakan hasil pendapatan perusahaan yaitu dari proyek yang diperoleh selama satu tahun.Biaya proyek merupakan biaya langsung yang dikeluarkan perusahaan untuk melaksanakan proyek, yang terdiri dari:

a. Biaya material, merupakan biaya untuk membeli bahan baku bagi keperluan proyek yang dilaksanakan perusahaan

b. Biaya upah, adalah biaya untuk membayar seluruh pekerja yang terlibat langsung dalam pelaksanaan proyek perusahaan

c. Biaya pemeliharaan proyek, merupakan biaya untuk melakukan service pada konsumen untuk memelihara proyek. Besarnya adalah 2\% dari biaya material dan biaya upah yang dikeluarkan

d. Biaya overhead proyek, adalah biaya tidak langsung lainnya untuk melaksanakan proyek yaitu biaya kendaraan, pemasaran, asuransi, konsumsi, sewa alat, pengobatan dan lain-lain biaya proyek.

El-Muhasaba, Vol. 7, No 1, Januari 2016 
Biaya operasi adalah biaya untuk melaksanakan kegiatansehari-hari perusahaan. Biaya ini terdiri dari:

a. Biaya gaji pegawai kantor

b. Biaya kantor yang terdiri dari biaya untuk membeli keperluan kantor, biaya telepon/fax, biaya listrik, biaya PDAM dan biaya sewa kantor

c. Biaya umum yaitu biaya untuk menunjang kelangsungan perusahaan yaitu biaya bank, biaya perjalanan dinas, biaya pajak/PBB dan biaaya lain-lain umum

d. Biaya penyusutan aktiva, yang terdiri dari biaya penyusutan kendaraan dan penyusutan inventaris kantor

\section{Analisis Laporan Laba Rugi tahun 2012 dengan Pendekatan Value Chain}

Biaya-biaya yang terdapat dalam laporan keuangan standar sebelumnya akan dikelompokkan dengan menggunakan pendekatan value chain. Biaya tersebut akan terbagi atas dua bagian yaitu biaya aktivitas umum dan biaya aktivitas pendukung.

\section{Biaya aktivitas utama}

1. Pemasaran

Biaya yang terjadi pada aktivitas ini adalah biaya pemasaran sebesar Rp. 58.921.000 yang merupakan biaya untuk memperoleh proyek sebagai sumber pendapatan perusahaan.Untuk memperoleh pekerjaan proyek maka perusahaan mengikuti tender, prakualifikasi atau melakukan penawaran pada perusahaan-perusahaan ataupun perorangan.

2. Perencanaan

Yang termasuk dalam aktivitas perencanaan adalah biaya gaji pegawai kantor teknik dan operasional Rp. 240.500.000, yaitu pegawai yang melakukan aktivitas perencanaan

3. Pelaksanaan

Biaya aktivitas ini adalah:

a. Biaya material untuk membeli material proyek Rp. 4.302.500.000. Biaya ini digolongkan sebagai aktivitas produksi karena digunakan sebagai input dari aktivitas pelaksanaan untuk diubah menjadi output.

b. Biaya upah pekerja proyek Rp. 2.585.000.000. Biaya ini termasuk dalam aktivitas pelaksanaan karena berhubungan langsung dengan proses pengubahan input menjadi output

c. Biaya overhead proyek yang terdiri dari biaya kendaraan, biaya konsumsi, biaya sewa alat, biaya lembur, pengobatan dan biaya lain-lain dengan total Rp. 309.996.500.

d. Biaya gaji pegawai kantor bagian proyek Rp. 286.000.000. 
4. Service, biaya yang terjadi adalah:

a. Biaya pemeliharaan proyek Rp. 137.750 .000

b. Biaya asuransi proyek Rp. 43.940 .500

Biaya aktivitas pendukung terdiri dari:

1. Pembelian

Biaya untuk membeli keperluan kantor Rp. 29.750.000. Biaya ini termasuk dalam aktivitas pembelian karena dikeluarkan untuk melakukan pembelian masukan yang digunakan dalam seluruh aktivitas perusahaan

2. Infrastruktur

Biaya yang terjadi dalam aktivitas ini terdiri dari :

a. Biaya gaji pegawai kantor bagian administrasi dan keuangan Rp. 260.000.000

b. Biaya kantor yang meliputi biaya telepon/fax, biaya listrik, biaya SDM dan biaya sewa kantor dengan total Rp. 126.607.660

c. Biaya umum yang meliputi biaya bank, biaya perjalanan dinas, biaya pajak/ PBB dan biaya lain-lain dengan jumlah Rp. 86.600.750.

d. Biaya penyusutan aktiva Rp. 96.000.000.

\section{Analisis Laporan Laba Rugi tahun 2013 dengan Pendekatan Value Chain}

Biaya-biaya yang terdapat dalam laporan keuangan standar tahun 2013 juga dikelompokkan dengan menggunakan pendekatan value chain. Biaya tersebut akan terbagi atas dua bagian yaitu biaya aktivitas umum dan biaya aktivitas pendukung.

\section{Biaya aktivitas utama}

1. Pemasaran

Biaya yang terjadi pada aktivitas ini adalah biaya tender, prakualifikasi sebesar Rp. 295.008.000 yang merupakan biaya untuk memperoleh proyek sebagai sumber pendapatan perusahaan.

2. Perencanaan

Yang termasuk dalam aktivitas perencanaan adalah biaya gaji pegawai kantor teknik dan operasional Rp. 240.500 .000 , yaitu pegawai yang melakukan aktivitas perencanaan

3. Pelaksanaan

Biaya aktivitas ini adalah:

a. Biaya material untuk membeli material proyek Rp. 2.957.000.000.

b. Biaya upah pekerja proyek Rp. 1.387.500.000. 
c. Biaya overhead proyek yang terdiri dari biaya kendaraan, biaya konsumsi, biaya sewa alat, biaya lembur, pengobatan dan biaya lain-lain dengan total Rp. 308.119.000.

d. Biaya gaji pegawai kantor bagian proyek Rp. 286.000.000.

4. Service, biaya yang terjadi adalah:

a. Biaya pemeliharaan proyek Rp. 86.890 .000

b. Biaya asuransi proyek Rp. 36.999.000.

Tabel 1. Perbandingan Laporan Laba Rugi Tahun 2012 dan Tahun 2013 dengan pendekatan Value Chain

\begin{tabular}{|l|r|r|r|r|}
\hline \multicolumn{1}{|c|}{ Aktivitas } & \multicolumn{1}{|c|}{$\mathbf{2 0 1 2}$} & & \multicolumn{1}{c|}{$\mathbf{2 0 1 3}$} & \\
\hline & \multicolumn{1}{c|}{ Jumlah } & \% & \multicolumn{1}{c|}{ Jumlah } & \% \\
\hline Pendapatan & 8.775 .000 .000 & 100 & 6.500 .000 .000 & 100 \\
\hline $\begin{array}{l}\text { Aktivitas } \\
\text { Utama }\end{array}$ & & & & \\
\hline Pemasaran & 58.921 .000 & 0,67 & 295.008 .000 & 4,54 \\
\hline Perencanan & 240.500 .000 & 2,74 & 240.500 .000 & 3,70 \\
\hline Produksi & 7.483 .496 .500 & 85,28 & 4.938 .619 .000 & 75.98 \\
\hline Service & 181.690 .500 & 2,07 & 123.889 .000 & 1,91 \\
\hline Total & $\mathbf{7 . 9 6 4 . 6 0 8 . 0 0 0}$ & $\mathbf{9 0 , 7 6}$ & $\mathbf{5 . 5 9 8 . 0 1 6 . 0 0 0}$ & $\mathbf{8 6 , 1 2}$ \\
\hline $\begin{array}{l}\text { Aktivitas } \\
\text { Pendukung }\end{array}$ & & & & \\
\hline Pembelian & 29.750 .000 & 0,34 & 31.500 .000 & 0,48 \\
\hline Infrastruktur & 569.208 .410 & 6,49 & 582.069 .750 & 8,95 \\
\hline Total & $\mathbf{5 9 8 . 9 5 8 . 4 1 0}$ & $\mathbf{6 , 8 3}$ & $\mathbf{6 1 3 . 5 6 9 . 7 5 0}$ & $\mathbf{9 , 4 4}$ \\
\hline Total Biaya & $\mathbf{8 . 5 6 3 . 5 6 6 . 0 0 0}$ & $\mathbf{9 7 , 5 9}$ & $\mathbf{6 . 2 1 1 . 5 8 5 . 7 5 0}$ & $\mathbf{9 5 , 5 6}$ \\
\hline Laba Bersih & $\mathbf{2 1 1 . 4 3 4 . 0 0 0}$ & $\mathbf{2 , 4 1}$ & $\mathbf{2 8 8 . 4 1 4 . 2 5 0}$ & $\mathbf{4 , 4 4}$ \\
\hline
\end{tabular}

Biaya aktivitas pendukung terdiri dari:

1. Pembelian

Biaya untuk membeli keperluan kantor Rp. 31.500.000. Biaya ini termasuk dalam aktivitas pembelian karena dikeluarkan untuk melakukan pembelian masukan yang digunakan dalam seluruh aktivitas perusahaan

2. Infrastruktur

Biaya yang terjadi dalam aktivitas ini terdiri dari:

a. Biaya gaji pegawai kantor bagian administrasi dan keuangan Rp. 260.000 .000

b. Biaya kantor yang meliputi biaya telepon/fax, biaya listrik, biaya SDM dan biaya sewa kantor dengan total Rp. 136.031.000

c. Biaya umum yang meliputi biaya bank, biaya perjalanan dinas, biaya pajak/ PBB dan biaya lain-lain dengan jumlah Rp. 86.538.750.

d. Biaya penyusutan aktiva Rp. 99.500.000. 
Setelah biaya-biaya pada laporan laba rugi dikelompokkan menurut aktivitasnya maka selanjutnya dinalisis dengan menggunakan pendekatan analisis profitabilitas. Dari analisis tersebut diketahui bahwa perusahaan $\mathrm{S}$ dapat menurunkan total biaya dari tahun 2012sebesar 97,59\% menjadi 95,56\% pada tahun 2013 yang berarti terjadi penurunan sebesar $2,03 \%$. Penurunan biaya tersebut terdiri dari penurunan biaya aktivitas utama dari tahun 2012 sebesar $90,76 \%$ menjadi $86,12 \%$ pada thun 2013 , yang artinya mengalami penurunan sebesar $4,64 \%$. Dan terdapat kenaikan biaya aktivitas pendukung dari tahun 2012 seebsar 6,83\% menjadi 9,44\% pada tahun 2013, yang berarti terdapat kenaikan sebesar 2,61\%.

Aktivitas utama terdiri dari:

1. Pemasaran

Pada aktivitas ini perusahaan mengalami kenaikan. Yaitu dari tahun 2012 sebesar $0,67 \%$ menjadi $4,54 \%$ pada tahun 2013 , yang artinya terjadi kenaikan sebesar $3,87 \%$. Hal ini dikarenakan perusahaan mengalami kebijakan untuk melakukan pemasaran secara lebih aktif. Perusahaan membuat rencana pemasaran, memasang iklan, menjaga hubungan pemasaran yang baik dengan pelanggan yang telah dimiliki dan memperluas hubungan dengan mencari konsumen baru. Pendapatan pada tahun 2012 berasal dari proyek tahun 2011 yang belum selesai. Sedangkan pada tahun 2013 perusahaan mengalami penurunan pendapatan yang mengharuskan perusahaan harus lebih aktif melakukan pemasaran.

2. Perencanaan

Perusahaan mengalami kenaikan dari tahun 2012 sebesar 2,74\% menjadi 3,70\% pada tahun 2013 yang berarti terdapat kenaikan $0,96 \%$ pada aktivitas ini, walaupun pada kenyataannya biaya yang terjadi yaitu biaya gaji pegawai kantor bagian teknik dan operasional adalah tetap. Terjadinya kenaikan disebabkan perusahaan mengalami penurunan pendapatan pada tahun 2013, sehingga proporsi biaya aktivitas ini terhadap pendapatan mengalami peningkatan

3. Pelaksanaan

Aktivitas ini mengalami penurunan dari sebesar $85,28 \%$ pada tahun 2012 menjadi $75,98 \%$ pada tahun 2013 , yang berarti terdapat penurunan $9,30 \%$. Penurunan ini disebabkan proyek yang diterima perusahaan pada tahun 2013 mengalami penurunan dibandingkan tahun 2012. Perusahaan juga mengalami optimasi dalam penggunaan bahan baku tanpa melupakan kualitas pekerjaan, melakukan pembelian pada pemasok yang memiliki harga yang lebih kompetitif serta lebih melakukan pengawasan terhadap bahan material di lokasi proyek agar tidak terjadi kehilangan bahan material. Hal ini dilakukan sebab harga bahan material meningkat sedangkan pekerjaan proyek jumlahnya menurun sedangkan perusahaan ingin meningkatkan ataupun mempertahankan profitabilitasnya.

4. Service

Terdapat penurunan dari tahun 2012 sebesar $2,07 \%$ menjadi $1,91 \%$ pada tahun 2013 yang artinya terdapat penurunan $0,16 \%$ pada aktivitas ini. Hal ini dikarenakan 
biaya material dan biaya upah proyek pada tahun 2013 mengalami penurunan. Sehingga biaya pemeliharaan proyek dan biaya asuransi juga mengalami penurunan.

Sedangkan biaya aktivitas pendukung mengalami kenaikan sebesar 2,61\%. Aktivitas pendukung terdiri dari:

1. Pembelian

Aktivitas ini mengalami kenaikan dari tahun 2012 sebesar $0,34 \%$ menjadi $0,48 \%$ pada tahun 2013, yang memiliki arti bahwa terjadi kenaikan 0,15\%. Terjadinya kenaikan pada aktivitas ini dikarenakan kenaikan harga beli keperluan kantor.

2. Infrastruktur

Terdapat kenaikan yaitu pada tahun 2012 sebesar $6,49 \%$ menjadi $8,95 \%$ pada tahun 2013, yang artinya terdapat kenaikan 2,47\%. Kenaikan ini disebabkan kenaikan biaya telepon/fax, biaya listrik, biaya ajak/PBB dan biaya penyusutan aktiva.Biaya telepon/fax mengalami kenaikan karena banyaknya pemakaian telepon yang tidak efisien oleh karyawan.

Pada tahun 2013 ketika pendapatan yang diterima perusahaan mengalami penurunan sebesar 25,92\% dari tahun 2012, ternyata perusahaan mengalami peningkatan laba sebesar $2,03 \%$. Hal tersebut menunjukkan bahwa perusahaan telah cukup mampu mengelola aktivitas internalnya.

Dengan analisis value chain maka aktivitas-aktivitas value chain dapat diketahui. Kemudian dapat dianalisis aktivitas mana yang membutuhkan perbaikan. Perusahaan selain melakukan efisiensi juga melakukan langkah yang dianggap mampu untuk menciptakan keunggulan bersaing yaitu:

1. Melakukan internal control penggunaan bahan material yaitu dengan adanya pembuatan purchase requisition terlebih dahulu sebelum melakukan pembelian bahan.Apabila terdapat kebutuhan material dalam suatu proyek maka Site Manager akan membuat purchase requisition. Setelah itu dilakukan analisa oleh Manager Teknik di kantor untuk menentukan apakah bahan material yang diminta tersebut memang benar dan tepat dibutuhkan dalam proyek. Apabila memang benar maka selanjutnya dibuat purchase order untuk melakukan pembelian material. Ketika bahan material diterima maka dibuat laporan penerimaan bahan untuk memastikan bahwa memang telah diterima. Sedangkan jika permintaan bahan material berlebihan maka Site Managerharus membuat purchase requisition baru. Adanya purchase requisition membuat pembelian bahan material lebih terkontrol sehingga penggunaannya lebih ekonomis dan efektif.

2. Melakukan analisa teknik dalam perhitungan penggunaan bahan Agar suatu proyek dapat berhasil maka aspek teknologi dan informasi harus diperhatikan. Analisa teknik dapat digunakan untuk mengelola agar sumberdaya efisien dan efektif dalam mencapai tujuan yang diharapkan.Hal ini akan sangat 
membantu dalam menentukan kebutuhan material secara efisien agar dapat menekan biaya pelaksanaan proyek.

Dengan menerapkan langkah tersebut perusahaan berupaya menciptakan keunggulan bersaing daripada pesaingnya dengan menawarkan harga yang lebih kompetitif dengan kualitas yang bermutu.Kualitas produk merupakan salah satu hal yang harus diperhatikan karena memiliki urgensi yang sangat tinggi dan berkontribusi besar terhadap komunikasi Word of mouth, retensi pelanggan, pembelian ulang, loyalitas bahkan pangsa pasar (Tjiptono dalam Lutfia, 2012). Keunggulan bersaing tersebut juga berguna untuk meningkatkan pelayanan terhadap konsumen terutama disaat-saat proyek yang dilaksanakan jumlahnya sedikit. Apabila konsumen puas atas hasil yang diterima maka akan memudahkan perusahaan melakukan pemasaran yang akhirnya meningkatkan pendapatan perusahaan.

\section{SIMPULAN}

Analisis laporan laba rugi dengan pendekatan value chainakan membantu perusahaan untuk mengetahui dan mengukur kinerja aktivitas-aktivitas nilainya yang mampu memberikan nilai tambah bagi kepuasan konsumen. Aktivitas nilai perusahaan terbagi atas dua yaitu aktivitas utama dan aktivitas pendukung.Aktivitas utama terdiri aktivitas pemasaran, perencanaan, pelaksanaan dan service. Sedangkan aktivitas pendukung adalah aktivitas pembelian dan infrastruktur perusahaanAktivitas yang memiliki pengaruh besar terhadap profitabilitas pada tahun 2012 apabila diurutkan adalah aktivitas pelaksanaan, infrastruktur, perencanaan, service, pemasaran dan pembelian. Sedangkan tahun 2013 adalah aktivitas pelaksanaan, infrastruktur, pemasaran, perencanaan, service dan pembelian. Aktivitas yang memiliki pengaruh besar dalam perusahaan adalah aktivitas pelaksanaan, yang dalam hal ini sudah tepat karena perusahaan bergerak dalam bidang pengerjaan proyekDari hasil analisis diketahui secara keseluruhan kinerja perusahaan tahun 2013 lebih baik daripada tahun 2012. Hal ini dapat dilihat dengan adanya peningkatan prosentase laba dari 2,41\% pada tahun 2012 menjadi 4,44\% pada tahun 2013.

\section{DAFTAR PUSTAKA}

Govindarajan, V., and Shank, J.K. 1993. Strategic cost management: The new tool forcompetitive advantage. Bandung: Free Press.

Kerzner, Harold. 2009. Project Management : A Systems Approach to Planning, Schedulling and Controlling $10^{\text {th }}$ edition. Australia: John Wiley and Sons.

Lutfia, Annisa. 2012. Analisa Pengaruh Value Chain Terhadap Persaingan Dalam Mencapai Kepuasan Pelanggan Pada Perusahaan Precast di Indonesia. Universitas Indonesia, Jakarta

Porter, Michael, E. 1985. Competitive Advantage: Creating and sustaining superior performance. Jakarta: Free Press.

El-Muhasaba, Vol. 7, No 1, Januari 2016 
Sugiyono. 2013. Metode Penelitian Pendidikan (Pendekatan Kuantitatif, Kualitatif, dan $R \& D)$. Bandung: Alfabeta. 